\title{
WRN wt Allele
}

National Cancer Institute

\section{Source}

National Cancer Institute. WRN wt Allele. NCI Thesaurus. Code C49413.

Human WRN wild-type allele is located within 8p12-p11.2 and is approximately $140 \mathrm{~kb}$ in length. This allele, which encodes Werner syndrome ATP-dependent helicase protein, is involved in the both the formation of DNA replication focal centers and the unwinding of single- and double-stranded DNA in a 3'-5' direction. Certain allelic variants of this gene cause Werner syndrome. 